\title{
Development of android based augmented reality video for tennis courts learning
}

\author{
Galang Sulaksono \\ Universitas Doktor Nugroho, Indonesia \\ Received: 03 February 2021; Accepted 23 April 2021; Published 29 July 2021 \\ Ed 2021; 6(2): 218-230
}

\begin{abstract}
This research aims to develop an android-based augmented reality application called AR Tennis. The resulted product is used as a medium for learning tennis courts courses. The AR Tennis application helps students understand the illustrations contained in courts tennis textbooks. The picture in the book which is originally only a silent illustration, with the help of the AR Tennis application, the image will move. The method used is MDLC (Multimedia Development Life Cycle). Testing the application using the blackbox method and the results are all components of the application function properly. From the results of the assessment of learning media experts obtained a value of 97.6 with a very good category. From the expert on tennis material, the score is 89.2 with a good category. And trials for students who take part in tennis court scored 92.14 in the appropriate category for use. Augmented reality technology is still not popular in the field of education. But going forward this technology will be very helpful in any study in the education.
\end{abstract}

Keywords: Development; android; augmented reality; tennis

d.

https://doi.org/10.25299/sportarea.2021.vol6(2).6361

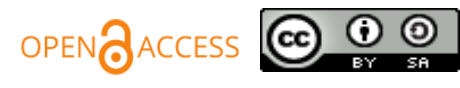

Copyright @ 2021 Galang Sulaksono

Corresponding author: Galang Sulaksono, Department of Physical Education, Health and Recreation, Universitas Doktor Nugroho, Magetan, Indonesia

Email: galang.27271@gmail.com

How to Cite: Sulaksono, G. (2021). Development of android based augmented reality video for tennis courts learning. Journal Sport Area, 6(2), 218-230. https://doi.org/10.25299/sportarea.2021.vol6(2).6361

\section{INTRODUCTION}

Court tennis is played by two players or four players at the same time with a partner of two players each (Kamal \& Imelda, 2011; Supriatna, 2016). Court tennis can be played by everyone without any age restrictions. This game uses a racket and ball and can be played singles or doubles (Sahan \& Erman, 2009). According to statistical data from Statistic and Data (2020) reported that tennis courts have around 1.2 billion fans in the world. In the data presented from all sports in the world, tennis ranks fourth under football, cricket, and hockey. Zetou (2012) said tennis is a medium that can maintain good health. This is enough to illustrate that tennis is very popular with people in the world. Besides that, tennis is also one of the subjects taught on campus which has a sports faculty.

Learning today requires educators to be more innovative in carrying out teaching. Educators must be able to design interesting educational activities for students. One of the innovations in learning is the use of technology (Al-Shara, 2015). Technology has entered into human life and society which makes it an important aspect for daily life, be it social life, education, profession and religion (Xavier \& Francis, 2017). Developing an understanding of cognitive, metacognitive, affective, and physiological requires educators to make effective learning using technology (Crompton et al., 2020). With the development of aspects of 
education in Indonesia, a technology is needed to further advance education in terms of science and technology. One way of applying technology in learning is by using textbooks.

Teaching materials that are still often and easy to use today are books. Books are always the first choice as learning aids. Textbooks provide great benefits in the teaching and learning process, in this case students in learning gain meaningful relationships to solve problems (Surahman \& Yeni, 2019). In addition to functioning to support educators in the learning process, books are also a source of knowledge for students (Asri, 2017). In a book, it does not only contain text which is the contents of the book, but there are also images that represent illustrations of the contents of the text. But the pictures in the book are just a silent illustration. This makes it a little difficult for the reader to describe the meaning of the image. Therefore we need a technology to help readers better understand the meaning of the illustrations. One technology that is currently being developed is Augmented Reality.

Augmented Reality is a technique that combines two-dimensional and three-dimensional virtual objects into a real three-dimensional sphere and then projects these objects in real time (Pamoedji \& Sanjaya, 2017). Dynamically AR is a technology that coats the real world with virtual or virtual information (Wu et al., 2013). Augmented Reality displays information through virtual objects that the user cannot detect with his or her own senses, which allows one to interact with the real world in different ways (Gopalan et al., 2016). Augmented Reality applications can improve the learning experience of students by inserting video, text, graphics, and audio into the real world (Tuli \& Mantri, 2015).

Research conducted by Al-Ansari (2017) only uses a single marker, namely one marker for all objects. So object recognition is less specific and confusing. Continued research from Agatha and Darmawiguna (2017) AR applications are developed without using markers, so that it would interfere with the recognition of certain objects, and supporting materials were still lacking for independent learning. The development of AR Tennis is different from the results of similar research and development that have been carried out before. This development integrates the AR Tennis application into a tennis textbook that has been prepared according to the rules of preparing a textbook. Where in the tennis textbook there is a Quick Respond Code (QR Code) which is used to scan images in the book using the AR Tennis application which can make images in the book move in the form of a video of court tennis practice according to the material in the chapter. Augmented reality technology in books has a positive effect on education not only in cognitive but also affective domains such as activeness, interactiveness, and student abilities (Tuli \& Mantri, 2015).

Based on the explanation above, this research is expected to produce a product that is used to support lectures, especially tennis courses. This developed application helps to understand the illustrations in the tennis textbook. Compared to other relevant research, this study includes a textbook that contains material about tennis and is integrated with augmented reality applications. Therefore, this research and development will use the MDLC method in developing textbooks and AR Tennis applications for teaching tennis courses.

\section{METHODS}

This research is conducted at the University of Nusantara PGRI Kediri Department of Physical Education, Health and Recreation with a research sample of 30 students. The sampling technique used purposive sampling, namely a sampling technique with special criteria by selecting students who take the tennis course. The data collection instrument uses a questionnaire. The scale used in this study is a Likert scale. Sugiyono (2011) said the Likert scale is used to measure the perceptions, opinions, and attitudes of a person or group of people about social phenomena. The form of the questionnaire for media experts and material experts is different. The media expert's questionnaire assessment includes book cover design, book layout, AR Tennis application design, marker design, and video objects. As for the material expert, the assessment questionnaire consists of material clarity, material understanding, material accuracy, material suitability, and material attractiveness. For users of the questionnaire, the assessment consists of clarity, understanding, accuracy, suitability, and attractiveness. The method used is MDLC (Multimedia Development Life Cycle), namely concept, design, material collection, assembly, testing, and distribution (Binanto, 2010). For the trial, this research involves an expert in learning media, an expert in tennis material, and 30 students who take a tennis course. 


\section{Concept}

This stage is the stage to determine the purpose and who the users of this application are. At this stage, the researcher conceptualizes for: a. Determine the purpose and benefits of the AR Tennis application, $b$. Determine who the users of the AR Tennis application are, c. Describe the concept of the AR Tennis application that will be developed.

\section{Design}

At this stage, specifications are made regarding the program architecture, style, appearance, and material requirements for the program. The design that will be made uses the interface design from the application menu display. The software used to develop the AR Tennis application is Unity 3D, and for interface design using Adobe Photoshop.

\section{Material Collecting}

This stage is the stage of collecting materials in accordance with the needs that are done. These materials include images, photos, videos, audio, and others obtained from the internet and the researchers' own sources. This stage can be done in parallel with the assembly stage. However, in some cases, the collecting material stage and the assembly stage will be carried out linearly and not in parallel.

\section{Assembly}

The assembly stage is the stage of making all multimedia objects or materials. Application development is based on the design stage, such as storyboards, use cases, or activity diagrams.

\section{Testing}

The testing stage is carried out after completing the assembly stage by running the application / program and seeing whether there are errors or not. The first stage at this stage is also known as the alpha testing stage (alpha test) whose testing is carried out by the maker or the maker's own environment. After passing the alpha testing, beta testing involving end use will be carried out.

\section{Distribution}

At this stage the application will be stored in a storage media. This stage can also be called the evaluation stage for the development of finished products so that they become better. Figure 2 is a picture of the flow of the learning media that will be built. The plot describes from the beginning to the end of the plot.

\section{RESULTS AND DISCUSSION \\ Concept}

The purpose of this application is as a learning medium for tennis courses and the benefit of this application is to make it easier to understand the illustrations in tennis textbooks. Users of this application are educators/lecturers and sports students who take tennis courses. This application runs on Android-based smartphone devices.

\section{Design}

At this stage, the system design is used to make applications from the initial design stage to the end.

\section{Use Case Diagram}

In Figure 1 below, the Use Case Diagram is the flow of the AR Tennis application process starting from the user when he first enters the application. In the application there are several main menus, namely AR Camera, Instructions for Use, Developer Profile, and the application exit button. 


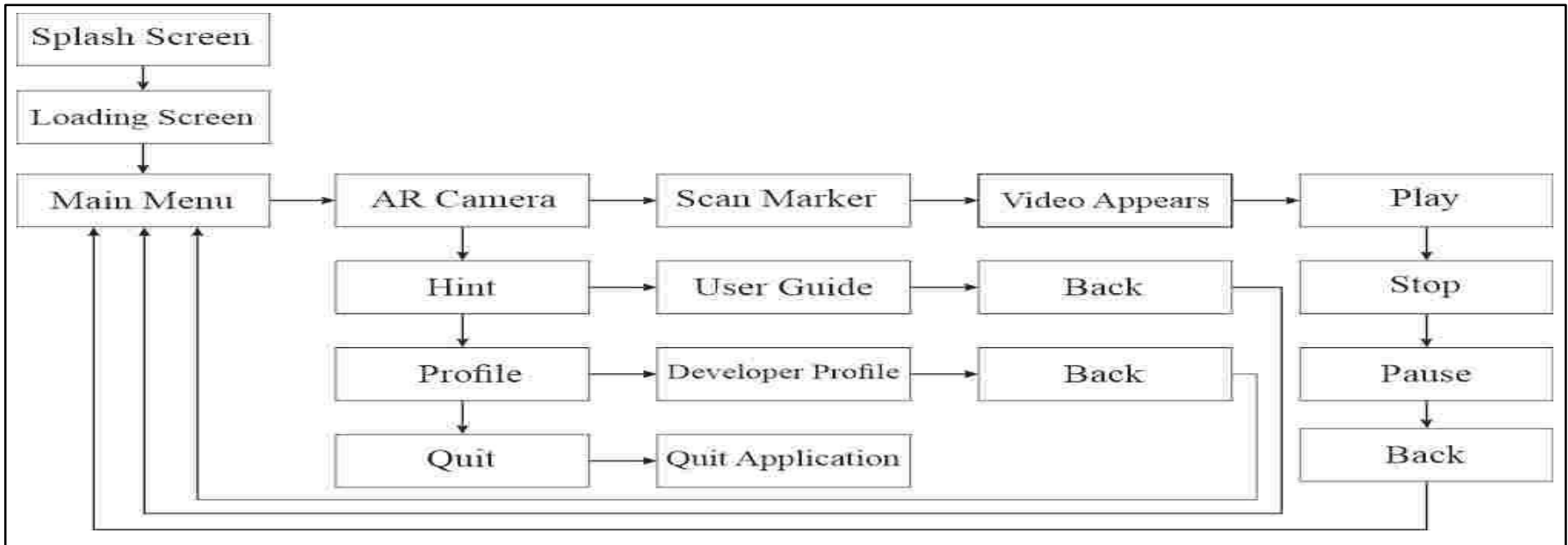

Figure 1. Use Case Diagram

\section{Activity Diagram}

The activity diagram below is about the workflow of the AR Tennis application. The user installs the AR Tennis application and then opens the application. The initial display is a splash screen then a loading screen, after that the main menu consisting of the AR Camera menu, instructions menu, profile menu, and application exit button. In the AR Camera menu, users will activate a camera that can be aimed at the markers available in the tennis textbook. When the camera is pointed at the marker, a video that matches the material in the chapter will appear. Users can return to the main menu by pressing the back button located at the top of the AR Camera screen. The instructions menu displays instructions on how to use the AR Tennis app. Users can return to the main menu by pressing the back button. The profile menu displays the application developer profile with a brief curriculum vitae in it. Users can return to the main menu by pressing the back button. The application exit menu closes the AR Tennis application.

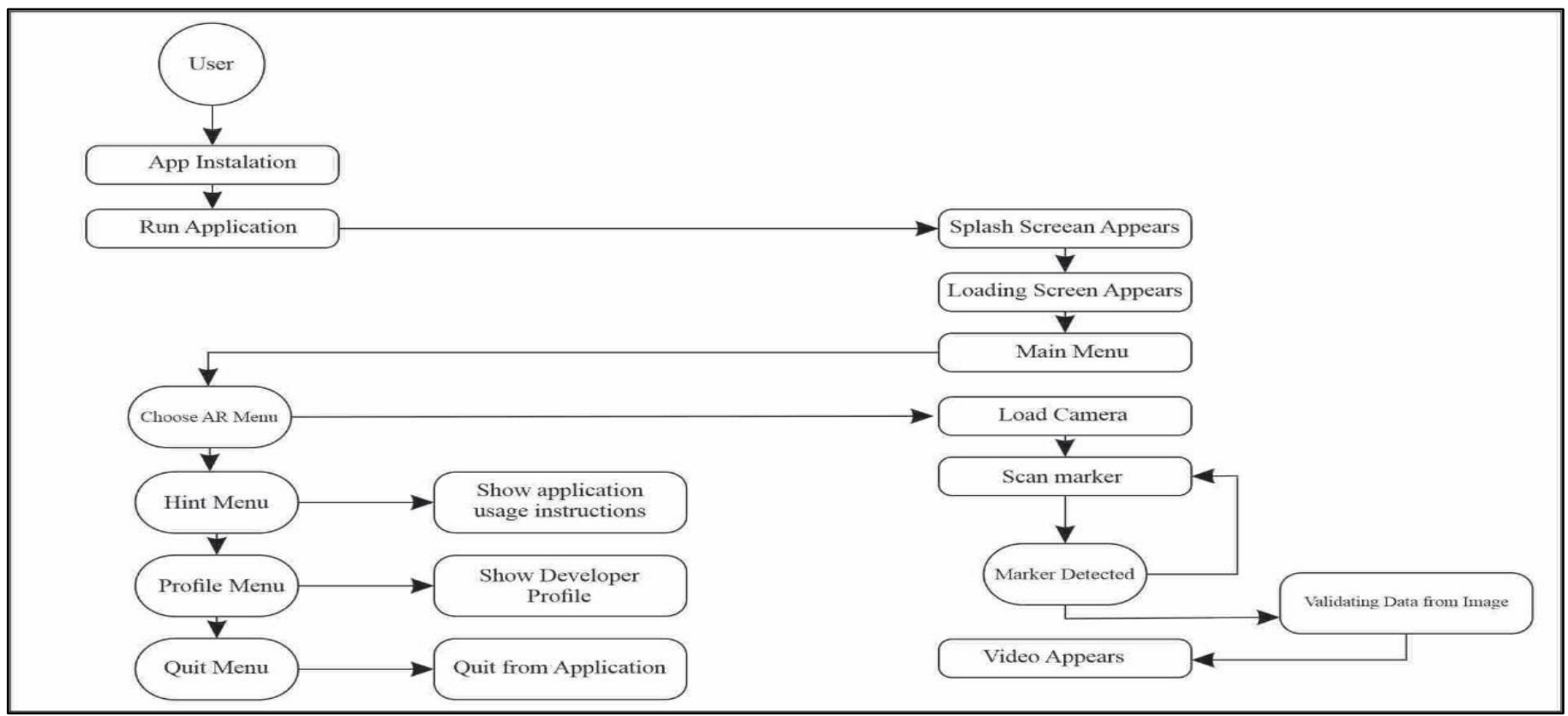

Figure 2. Activity Diagram

\section{Material Collecting}

At this stage, materials related to teaching/learning materials are obtained from interviews with lecturers who teach tennis courses, interviews with students who take tennis courses, reading books, and looking for 
other sources from the internet. For materials related to Augmented Reality, the authors get material from reference books, and the internet.

To develop applications, hardware and software are needed. The hardware used is a set of computers with specifications: Processor Intel Core i3 3240, 8 GB RAM, and 2GB Nvidia GTX 750Ti VGA. The software used is Windows 10 Pro as the Operating System, Unity 3D for developing the AR Tennis application, Adobe Photoshop CC 2017 for interface design, and Adobe Premiere Pro CC 2017 used for video processing and editing. Making videos uses a single lens camera with mp4 format. Editing uses Adobe Premiere Pro software by adding text and background audio. Video editing is combined with slow motion which aims to make the motion video clearly visible.

\section{Assembly}

At this stage, making applications using Unity 3D software, while for image design using Adobe Photoshop. The process of making an application based on design is as follows:

\section{AR Tennis App Creation}

The AR Tennis application is developed using Unity 3D software version 5.1 with the help of languages C\#.

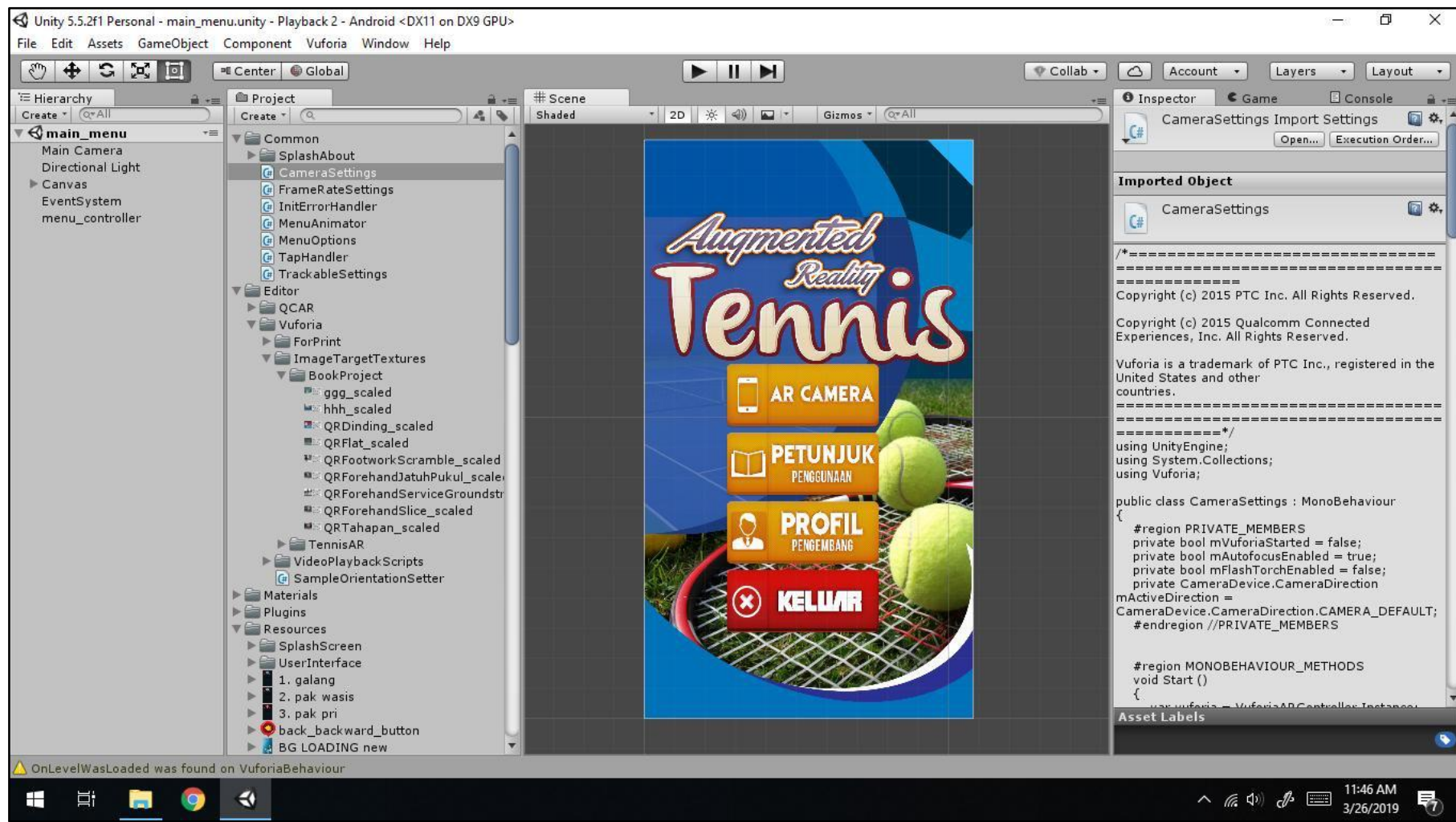

Figure 3. Display of Program Unity 3D

\section{Marker Creation}

Making this AR tennis application uses a marker as a marker. Each chapter or each material will have a different marker shape. The marker is in the form of a QR Code (Quick Respond Code) which is combined with illustrations of material in certain chapters. Making a marker from a marker generator and combining it with a tennis illustration photo use Adobe Photoshop software. An example of a marker image that has been made can be seen in Figure 4 below. 


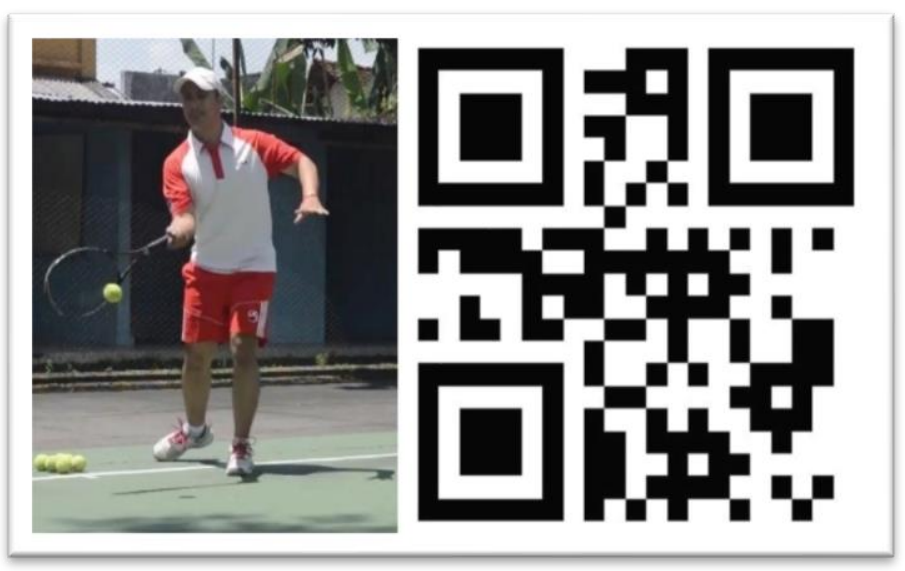

Figure 4. Example of Marker

\section{Splashscreen Page}

A splashscreen page that says Made with Unity 3D will automatically appear showing the name of the application used to develop, namely Unity3D. This scene appears with a duration of 2 seconds and will go directly to the next scene. The splashscreen page can be seen in Figure 5.

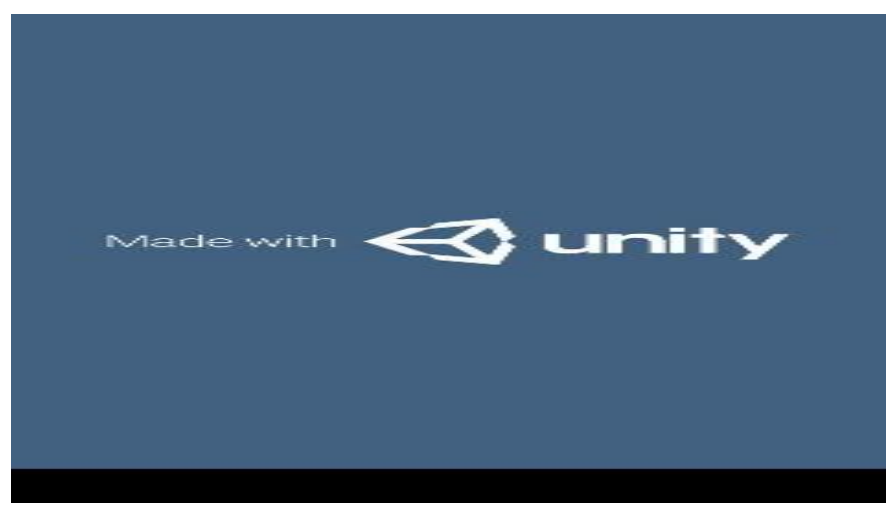

Figure 5. Splashscreen Page

\section{Page Loading Screen}

The loading screen page displays a silhouette image of a person playing tennis with a mix of colors to make it look attractive. This image is designed using Adobe Photoshop and implemented into an application using Unity 3D. This scene appears with a duration of 2 seconds and will go directly to the next scene. The loading screen page can be seen in Figure 6.

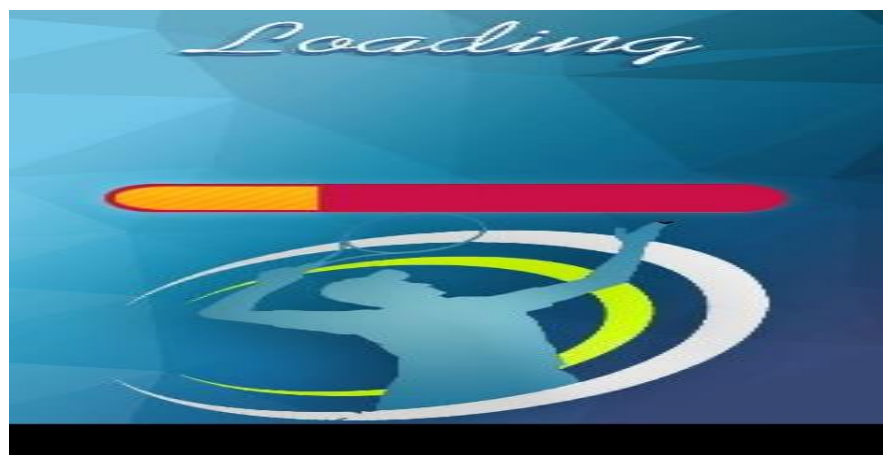

Figure 6. Loading Screen Page 


\section{Main Menu Page}

The main menu page has 4 buttons, namely AR Camera, Instructions for use, Developer profile, and the application exit button. The background and buttons are designed using Adobe Photoshop and implemented into the application using Unity 3D. The main menu page can be seen in Figure 7.

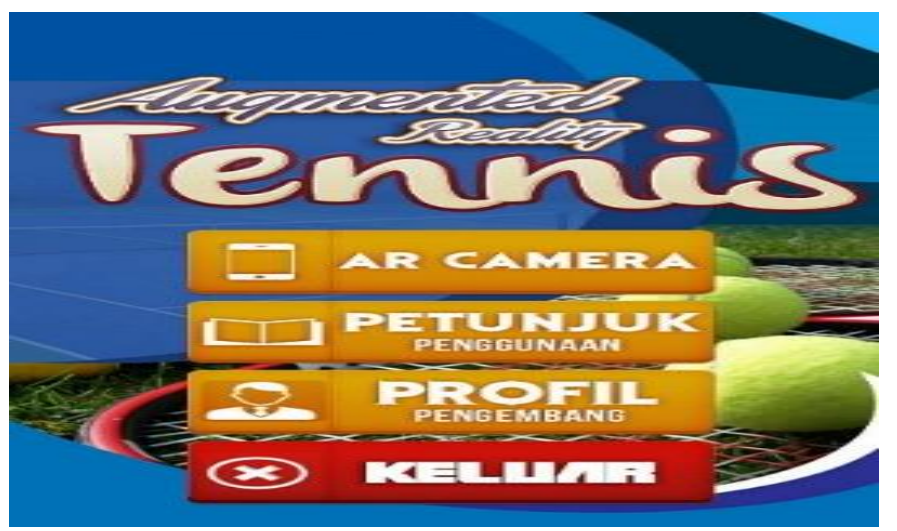

Figure 7. Main Menu Page

\section{AR Camera Page}

The AR Camera button will take us to the AR Camera display (Figure 5), and it can be directed to a tennis book that is equipped with a QR Code or can be called a marker. When the AR Camera is directed at the image marker, a video will appear ready to be played by pressing the play button on the video. To make the video display fullscreen, it can be done by tapping 2 times on the video and selecting fullscreen. If you want to stop the video, you can do it by tapping once on the video. To exit the AR Camera view, you can do this by pressing the menu button on the top right. Figure 8 is shown before using the AR Tennis application, the image is only a marker. And when using the AR Tennis application the image will move.
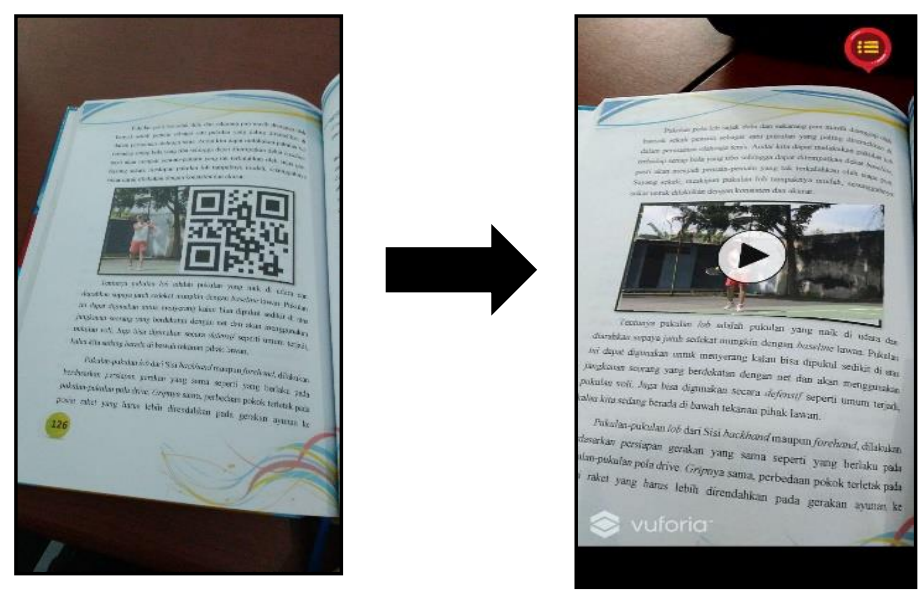

Figure 8. AR Camera Page

\section{Hint Page}

The user manual display (Figure 9) shows how to use the AR Tennis application. The next button serves to display the next instructions for use in sequence. 


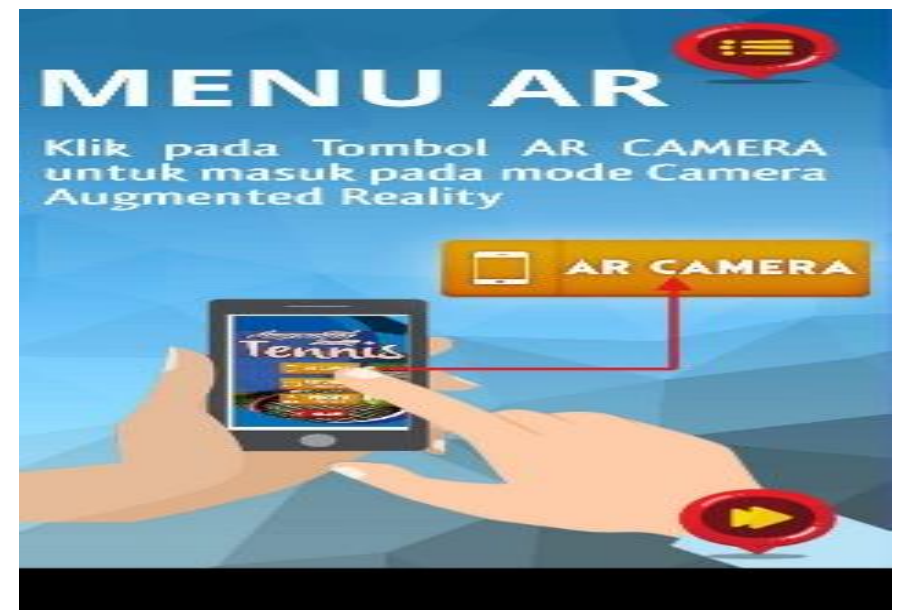

Figure 9. Hint Page

\section{Profile Page}

The Profile menu display (Figure 10) displays the profile of the developer. Profiles can be read by swiping your finger up or down on the resume text. To return to the main menu by pressing the menu button located in the upper right corner.

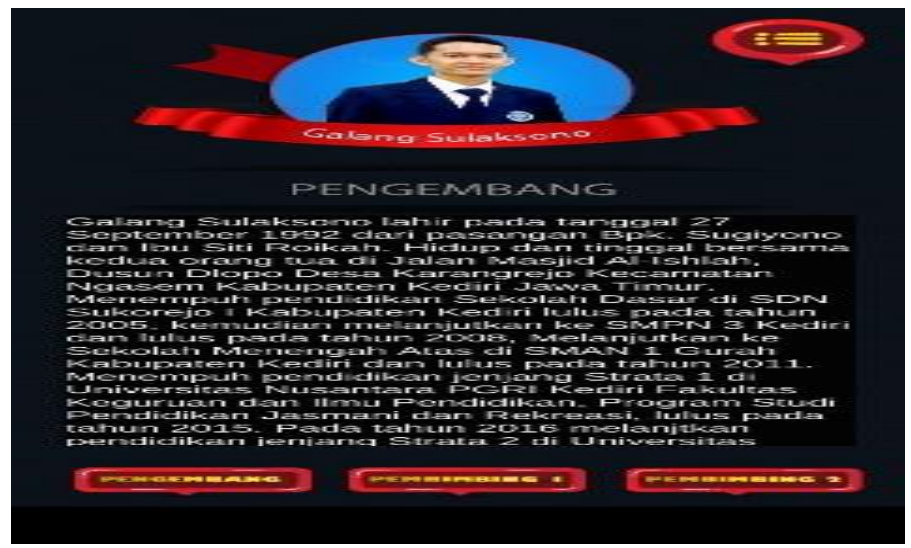

Figure 10. Page Profile

\section{Specifications of Court Tennis Textbook}

The textbook is printed in B5 size $(18.2 \times 25.7 \mathrm{~cm})$ containing 11 tennis materials consisting of the history of tennis, facilities and infrastructure, how to hold a racket, ball feeling, forehand groundstroke, backhand groundstroke, volley, lob, dropshot, overhead, service, rules, and arbitration of tennis courts.

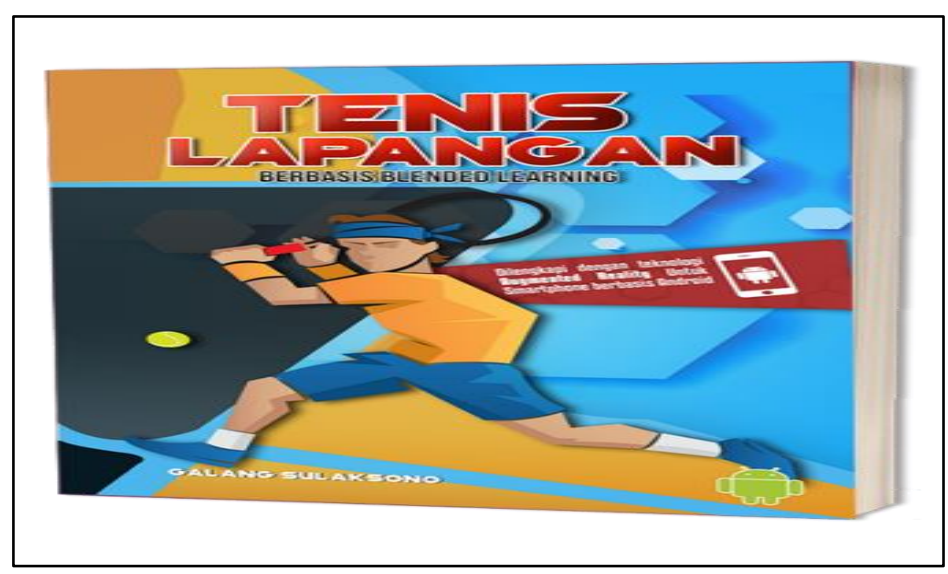

Figure 11. Display of Courts Tennis Text Book 


\section{Testing}

The testing stage is carried out after the assembly stage is completed by running the application/program to find out whether there are errors or not. At this stage, testing is carried out using blackbox testing. This blackbox method is a program testing based on the function of the program. The purpose of this blackbox testing method is to find malfunctions in the program. Blackbox testing focuses on the functional requirements of the software (Pressman, 2010). This test allows the system analysis to obtain input conditions that do all the functional requirements of the application. The test results can be seen in table 1.

Table 1. Blackbox Test

\begin{tabular}{|c|c|c|c|c|}
\hline No & Object & Sub Object & Functioning & Not functioning \\
\hline 1 & APK Instalation & & $\checkmark$ & \\
\hline 2 & Splashscreen Page & & $\checkmark$ & \\
\hline 3 & Loading Screen Page & & $\checkmark$ & \\
\hline \multirow{4}{*}{4} & \multirow{4}{*}{ Main Menu } & AR Camera Button & $\checkmark$ & \\
\hline & & Hint Button & $\checkmark$ & \\
\hline & & Profile Button & $\checkmark$ & \\
\hline & & Exit Button & $\checkmark$ & \\
\hline 5 & AR Camera Button & Back Button to Main Menu & $\checkmark$ & \\
\hline \multirow{4}{*}{6} & \multirow{4}{*}{ Hint Button } & Button of Next 1 & $\checkmark$ & \\
\hline & & Button of Next 2 & $\checkmark$ & \\
\hline & & Button of Next 3 & $\checkmark$ & \\
\hline & & Back Button to Main Menu & $\checkmark$ & \\
\hline \multirow{2}{*}{7} & \multirow{2}{*}{ Profile Button } & Text Scroll & $\checkmark$ & \\
\hline & & Back Button to Main Menu & $\checkmark$ & \\
\hline
\end{tabular}

(Source: Research Data, 2019)

\section{Usability Test}

The first test is the assessment of media experts. The assessment uses a questionnaire filled out by media experts. The results of the assessment with the highest percentage on the design of the book cover and marker with a value of $100 \%$. The cover design uses a flat model that looks simple and attractive to readers. The marker design uses a QR Code (Quick Respond Code) model marker which is currently widely used instead of the old-style barcode and all brands work well.

The lowest percentage is obtained in the layout of the book. The layout of the book gets a low score because the arrangement is not consistent and there are parts that are not neat. The results of the assessment of the AR Tennis application and textbooks received an average score of $97.6 \%$ with details of the assessment points shown in graph 1 below.

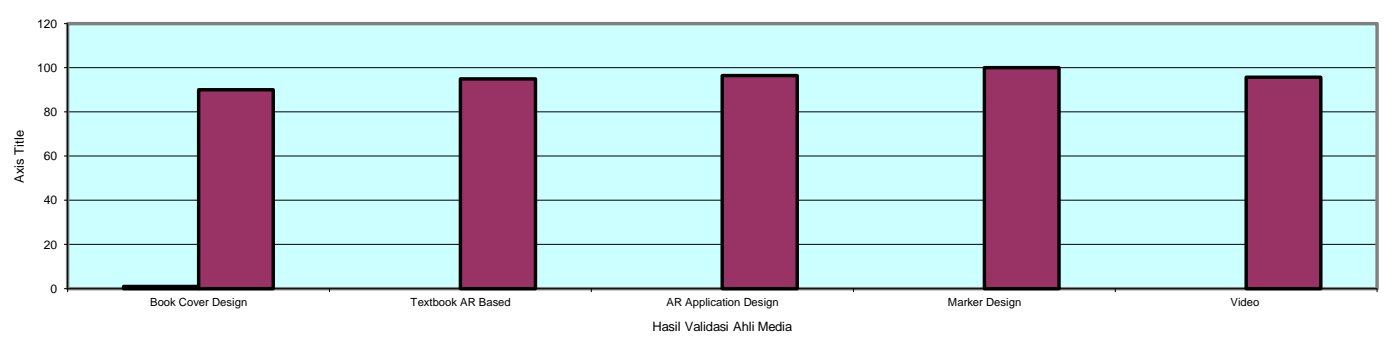


The next test is the assessment of the content and material of the tennis textbook by a courts tennis material expert. The highest percentage is obtained in the aspect of accuracy and clarity of the material with a value of $91.7 \%$. The lowest percentage is in the attractiveness aspect with a value of $85.4 \%$. The courts tennis material in the book is considered less interesting because there is no additional material or additional exercises to attract students' interest to explore and learn more about tennis. The results of the average value of material experts is $89.2 \%$ with details of the assessment points can be seen in Graph 2 below.

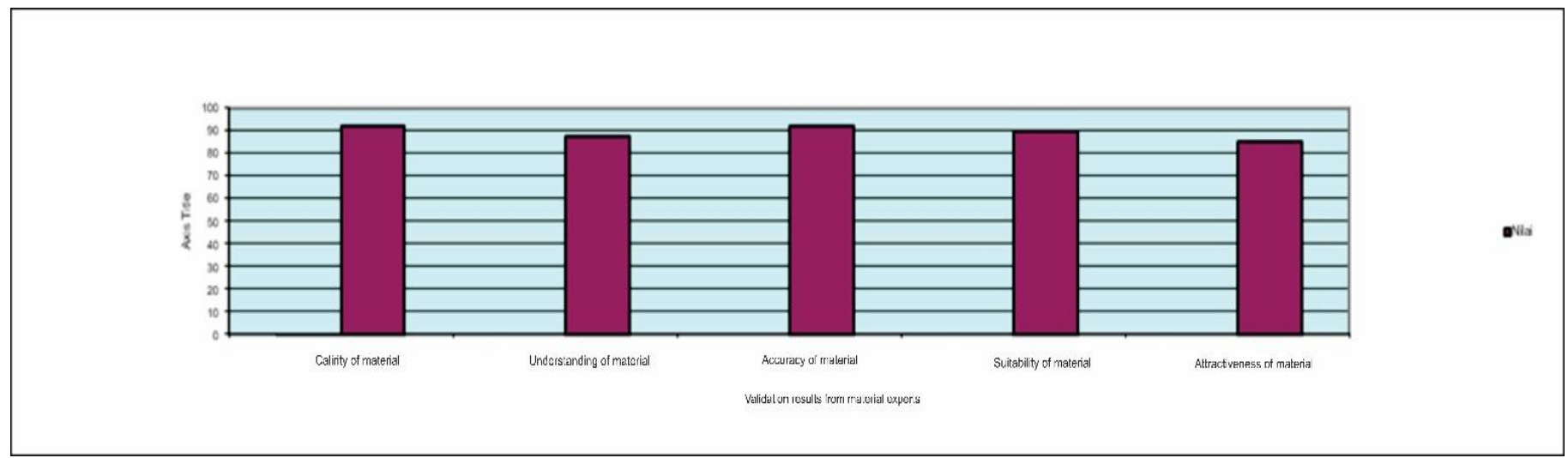

Graph 2. Result Material Expert Validation

After that, it is tested on 30 students who take the tennis course. Students are allowed to try the AR Tennis application and then fill out the questionnaire that has been provided. The highest percentage is in the aspect of material clarity with a value of $92.50 \%$. The lowest percentage is the same as the results from material experts, namely the attractiveness aspect with a value of $91.67 \%$. The average score obtained is $92.14 \%$ with details of the assessment points can be seen in Graph 3 below.

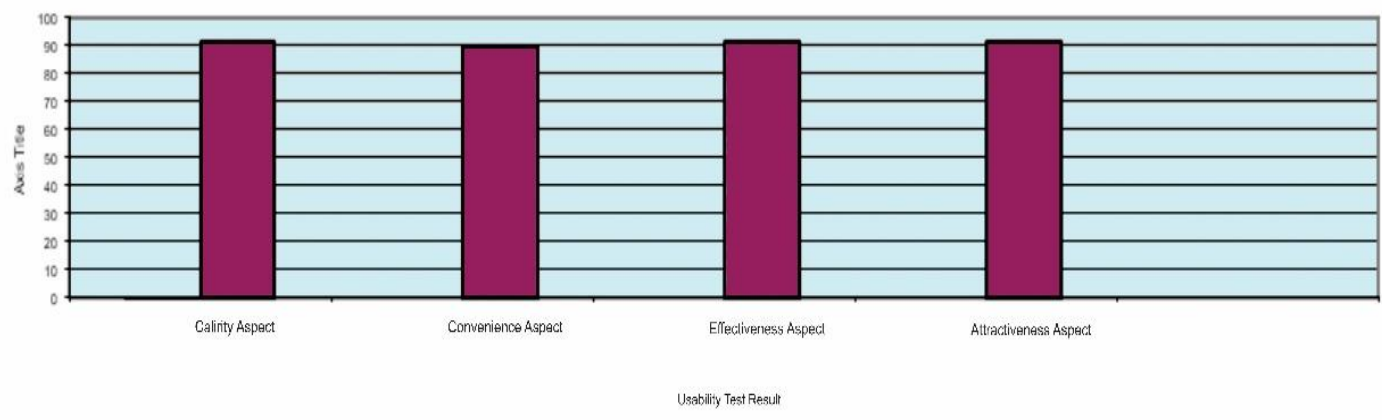

Graph 3. Result of Respondent Usability Test

\section{Distribution}

At this stage the distribution of the application is stored in the storage media. This AR Tennis application is based on android mobile, so the author saves this application on google drive so that it is easier to download and go directly to the smartphone for installation.

The use of technology in education is a good innovation and must be developed in a sustainable manner. If we are to end unsustainable thinking and practices, we need a change in the education system to guide us towards a prosperous and sustainable future (Burbules et al., 2020). Teachers who focus on technology integration have the potential to have a positive influence on students to use technology (Wilson et al., 2020).

From the presentation of the data that has been presented, it can be concluded that AR Video products for tennis learning can be used as learning media. Courts tennis learning is carried out at the college level. By 
utilizing AR technology, learning can run well and attract the enthusiasm of students. In line with the opinion of Kesim and Ozarslan (2012) that a new approach using AR technology increases the effectiveness and attractiveness of teaching and learning. This makes the integration between traditional learning and modern visualization in the use of AR (Coimbra et al., 2015).

In Indonesia, there has been a lot of research on Augmented Reality technology that is used in the field of sports education. One of them is research from Putra (2017) where the difference between his research and this research is the use of marker media, in this study the marker has been integrated with the tennis textbook, while the research conducted Putra (2017) without using markers. So in this study, in addition to using AR technology, users can still use textbooks as learning reference materials. Reading books as an important activity, in the use of books it is able to develop human reason and abilities (Benawi, 2012). Another research conducted by Al-Ansari (2017), the study only used one marker for all objects. While in this study each object uses different markers, this makes it easier for users to display objects according to what is being studied at that time.

This AR application is developed with a simple interface that does not confuse users. Instructions for use are also presented with images that make it easier for users to operate this AR application. Seems like what was said by Roth (2017) interface design focuses on interactively implemented generic operations or functions that allow users to manipulate views. With an attractive and simple interface makes it easy for users to operate and learn. Thanks to AR technology, it is possible to prepare effective and interesting technology-based teaching materials (Sahin \& Yilmaz, 2020).

\section{CONCLUSION}

Research and development of Augmented Reality technology in the field of physical education and health is still very limited in Indonesia. This is the main motivation for researchers to develop an AR tennis application accompanied by a tennis textbook. Through this application, the image that is originally not moving is displayed in the form of a video so that it is expected to increase students' understanding of tennis material. The results of the evaluation of this application using the blackbox method prove that the application components are functioning properly. Furthermore, the results of the assessment by the learning media experts obtained a score of 95.46 in the very good category and the expert on tennis material obtained a score of 89.2 in the good category. In general, through the evaluation of the test results to students, AR tennis media is very feasible to use with a percentage of $92.14 \%$. The limitations of this study can be seen in the material presented is limited to the material available in the tennis textbook only. In addition, the AR Tennis application is also limited to users of Android-based devices. Furthermore, the limitations of researchers to understand programming languages make this research and development need to be refined so that it becomes a better and more stable application when used. Suggestions for further research are the addition of features such as being able to display 3D (3-dimensional) objects and support for iOS-based smartphone devices.

\section{REFERENCES}

Agatha, B. H., \& Darmawiguna, G. M. (2017). Pengembangan Aplikasi Augmented Reality Markerless Pengenalan Dan Teknik Dasar Bola Basket. Kumpulan Artikel Mahasiswa Pendidikan Teknik Informatika (KARMAPATI), 6(3), 247. https://doi.org/10.23887/karmapati.v6i3.12058

Al-Shara, I. (2015). Learning and Teaching Between Enjoyment and Boredom As Realized By the Students: a Survey From the Educational Field. European Scientific Journal, 11(19), 1857-7881.

Al-Ansari. (2017). Penerapan Augmented Reality Dalam Pengenalan Peralatan Olahraga Tenis Meja Berbasis Android. Thesis. Universitas Sumatera Utara. 
Asri, A. S. (2017). Telaah Buku Teks Pegangan Guru Dan Siswa Pada Mata Pelajaran Bahasa Indonesia Kelas Vii Berbasis Kurikulum 2013. RETORIKA: Jurnal Ilmu Bahasa, 3(1), 70-82. https://doi.org/10.22225/jr.3.1.94.70-82

Benawi, I. (2012). Perpustakaan Kafe dan Warkop adalah Sebuah Perpustakaan Inovasi Masa Kini. Jurnal Iqra, 6(2), 1-11.

Binanto, I. (2010). Multimedia Digital - Dasar Teori dan Pengembangannya. Yogyakarta: Penerbit Andi.

Burbules, N. C., Fan, G., \& Repp, P. (2020). Five trends of education and technology in a sustainable future. Geography and Sustainability, 1(2), 93-97. https://doi.org/10.1016/j.geosus.2020.05.001

Coimbra, M. T., Cardoso, T., \& Mateus, A. (2015). Augmented Reality: An Enhancer for Higher Education Students in Math's Learning? Procedia Computer Science, 67, 332-339. https://doi.org/10.1016/j.procs.2015.09.277

Crompton, H., Bernacki, M., \& Greene, J. A. (2020). Psychological foundations of emerging technologies for teaching and learning in higher education. Current Opinion in Psychology, 36, 101-105. https://doi.org/10.1016/j.copsyc.2020.04.011

Gopalan, V., Zulkifli, A. N., Fadziana, N., Mohamed, F., \& Alwi, A. (2016). Augmented Reality Books For Science Learning-A Brief Review. International Journal of Interactive Digital Media, 4(1), 22894098 .

Kamal, \& Imelda. (2011). Ruang Olahraga. Semarang: PT. Gramedia.

Kesim, M., \& Ozarslan, Y. (2012). Augmented Reality in Education: Current Technologies and the Potential for Education. Procedia - Social and Behavioral Sciences, 47(222), 297-302. https://doi.org/10.1016/j.sbspro.2012.06.654

Pamoedji, A. K., \& Sanjaya, M. R. (2017). Mudah Membuar Game Augmented Reality (AR) dan Virtual Reality (VR) dengan Unity 3D. Alex Media Computindo.

Pressman, R. S. (2010). Rekayasa Perangkat Lunak: Pendekatan Praktisi (Buku Satu). Yogyakarta: Penerbit Andi.

Putra, P. A. M., Darmawiguna, G. M., \& Pradnyana, G. A. (2017). Pengembangan Aplikasi Augmented Reality Markerless Teknik Dasar Olahraga Bulutangkis. Karmapati, 6(3), 329-337. https://doi.org/10.23887/karmapati.v6i3.11902

Roth, R. (2017). User Interface and User Experience (UI/UX) Design. Geographic Information Science \& Technology Body of Knowledge, 2, 1-10. https://doi.org/10.22224/gistbok/2017.2.5

Sahan, A., \& Erman, K. A. (2009). The Effect of the Tennis Technical Training on Coordination Characterictics. The Open Sports Medicine Journal, 3(1), 59-65. https://doi.org/10.2174/1874387000903010059

Sahin, D., \& Yilmaz, R. M. (2020). The effect of Augmented Reality Technology on middle school students' achievements and attitudes towards science education. Computers and Education, 144, 103710. https://doi.org/10.1016/j.compedu.2019.103710 
Statistic \& Data. (2020). Most Popular Sports in the World - (1930/2020). https://statisticsanddata.org/mostpopular-sports-in-the-world/

Sugiyono. (2011). Metode Penelitian Kuantitatif dan R\&D. Bandung: Alfabeta.

Supriatna. (2016). Tenis Lapangan Untuk Perguruan Tinggi. Malang: UM Press.

Surahman, F., \& Yeni, H. O. (2019). Pengembangan Buku Ajar Mata Kuliah Renang Bagi Mahasiswa Pendidikan Jasmani Kesehatan dan Rekreasi. Journal Sport Area, 4(1), 218-229. https://doi.org/10.25299/sportarea.2019.vol4(1).2413

Tuli, N., \& Mantri, A. (2015). Augmented Reality as Teaching Aid: Making Chemistry Interactive. Journal of Engineering Education Transformations, Special Issue, 188-191. https://doi.org/10.16920/ijerit/2015/v0i0/59624

Wilson, M. L., Ritzhaupt, A. D., \& Cheng, L. (2020). The impact of teacher education courses for technology integration on pre-service teacher knowledge: A meta-analysis study. Computers and Education, 156, 103941. https://doi.org/10.1016/j.compedu.2020.103941

Wu, H. K., Lee, S. W. Y., Chang, H. Y., \& Liang, J. C. (2013). Current status, opportunities and challenges of augmented reality in education. Computers and Education, 62, 41-49. https://doi.org/10.1016/j.compedu.2012.10.024

Xavier, F., \& Francis, M. (2017). Use of Multimedia (ICT) as a Educational Tool in High School EducationA Study. Amity Journal of Media \& Communication Studies, 7(1), 31-37.

Zetou, E., Koronas, V., Athanailidis, I., \& Koussis, P. (2012). Learning tennis skill through game Play and Stay in elementary pupils. Journal of Human Sport and Exercise, 7(2), 560-572. https://doi.org/10.4100/jhse.2012.72.19 